\title{
The Relative Effectiveness of Three Types of Traps for Small Mammals in Some Peruvian Rodent Communities
}

\author{
John J. PIZZIMENTI
}

\begin{abstract}
Pizzimenti J. J., 1979: The relative effectiveness of three types of traps for small mammals in some Peruvian rodent communities. Acta theriol., 24, 25: 351-361 [With 5 Tables]

Comparisons were made among species and size classes caught by three commonly used, small-mammal traps. Results suggest that trap design can bias estimates of size variation and species diversity. McGill rat traps are more effective for trapping larger species. Sherman livetraps are more effective for trapping the smaller phenotypes and species. Museum Special snap traps were the most effective in that they caught a broad size spectrum of individuals and species. Additionally, Niuseum Specials obtained the largest proportion of the composite catch; live traps the smallest proportion and rat traps were intermediate. Results of these analyses should serve as a caveat to students of mammalian populations because the use of specimens and trapping data may sometimes carry hidden bias based on method of capture.

[Dept. Biol. Sci., Univ. Illinois, Chicago, Illinois 60680, USA and Field Museum Nat. Hist., Chicago 60605, USA].
\end{abstract}

\section{INTRODUCTION}

Mammalogists use a variety of traps for many specific reasons (M a nville, 1949) but the primary objectives can be grouped under two general headings: (1) to determine species composition and density, and (2) to characterize phenotypic or genotypic aspects of a population. Because most types of small mammals are difficult to observe, much of our knowledge of them is based on specimens captured with traps. Such devices extend our "vision " but their power, resolution and limitations must be understood to obtain realistic inferences from trapping data.

The potential danger of sampling bias because of trap selectivity has long been recognized ( $\mathrm{D}$ i c e, 1931), especially by those whose primary goal is to estimate community structure and density. Trap response, the proneness to enter traps, is a complex and difficult phenomenon to assess but undoubtedly involves behavior (Morris, 1968; Grant, 1970; $\mathrm{N}$ e a l \& Cock, 1969; Van V leck, 1968), food preferences and availability (Fitch, 1954; Patric, 1970; Smith \& B lessing, 1969), and even weather conditions (G e n tr y \& O d u m, 1957). 
One obvious source of potential bias is the trap design itself. Livetraps permit mark-recapture techniques, protein electrophoresis, karyology and other applications but are bulky, more costly and more difficult to use than snaps. Further drabacks may include lower effectiveness compared to snaps, underestimation of population density and biasing of sex ratios (W e in e r \& $\mathbf{S} \mathrm{m}$ it h, 1972; D a l b y \& $\mathrm{S}$ tr a n e y, 1976; Van V le ck, 1968; S m ith, 1968; D u r a n, 1969). Other studies, however, report that live traps are equally effective (Morris, 1955; Gra y, 1943; D a l b y \& S trane y, 1976) or even better (C o ck r u m, 1947; S e a l a n d e r \& J a m es, 1958) when compared to snaps.

The objective of most of these analyses has been to evaluate potential trap bias for species composition and density. Few studies have examined potential phenotypic bias. N e a 1 \& C o c k (1969) compared catches made from two types of snap traps in some African rodent communities for both species composition and weight differences. They found that traps biased the composition of their catch and the body weight of the catch both intra- and interspecifically. G r a n t (1970) noted a bias in the use of a single type of Longworth live-trap. Variation in the trip mechanism influenced species-specific trap response which was attributed to phenotypic (weight) differences and behavioral differences between species.

As part of a larger study of communities of small mammals in the Ande:s mountains of southern Peru, I performed an analysis of relative trap effectiveness of three commonly used commercially available smallmammal traps. These include two spring-loaded killing traps and one live-catch design.

\section{METHODS AND MATERIALS}

\subsection{Traps and Traplines}

The McGill Can't Miss Four-Way rat trap (McGill Metal Products, Marengo, Illinois) measures $180 \times 87 \mathrm{~mm}$ and consists of a double spring-loaded killing bar. The springs are easily detached and were armed only on one side to prevent specimen damage. The Museum Special (Animal Trap Company, Lititz, Pennsylvania) measures $70 \times 135 \mathrm{~mm}$ and has a unified single spring killing bar. The large size, folding Sherman live trap (H. P. Sherman, Deland, Florida) is a rectangular aluminum box measuring $75 \times 90 \times 230 \mathrm{~mm}$ with a spring-loaded door.

Standardized trap lines consisted of 25 stations spaced at $10 \mathrm{~m}$ intervals. Each station had a live-trap and a snap trap; Museum Specials at odd-numbered stations and rat traps at even-numbered stations. The two traps were placed several meters apart to minimize attraction by one and capture by the other. The catch in livetraps was distributed equally between odd and even numbered stations suggesting that any interaction between traps was minor or non-existent. Bait was rolled oats. Traps at each station were set firmly on the substrate in places adjudged to be most effective. Although they were set by more than one person, no one specialized 
in setting any particular design. All three types were maximized for release sensitivity throughout the study. Trap lines were maintained usually for three consecutive days and checked twice daily, morning and evening. Trapped animals were removed immediately upon capture and the trap reset. Three days is considered sufficient time to estimate composition and density of small rodent communities (Morris, 1968; Pucek O $1 \mathrm{szewski}, 1971$ ) and our records indicate capture rates usually diminished to near zero by the rinal period of trapping. Although all three types of traps were occasionally lost during field work, losses were minimal and adjusted for in the statistical analyses.

At each field station several to many trap lines were established on an elevational and habitat gradient to obtain a broad sample of the small mammal fauna of a region. Trapping was carried out at seven different regions, mostly on the altiplano of southern Peru. Localities are available on request.

\subsection{Technieal Treatment}

Weights were recorded in the field to one gram using a spring-loaded Pesola scale with a 100 gram maximum capacity. Standard statistics, analyses of variance, and Chi-square tests were performed on a Hewlett Packard 65 electronic calculator using Stat Pac I program library. Additionally, the SPSS program package (Nie et al., 1975) at the University of Illinois computation center was used to spot check statistics and to test for normality $\left(g_{1}, g_{2}\right)$ and homogeneity of sample variances (Sokal \& Rohlf, 1969). All samples appeared to have homogeneous variances and most demonstrated normal distributions reinforcing the reliability of tests of statistical significance. Taxonomy follows Pear s on $(1951,1958,1972)$.

\subsection{Hypotheses Tested}

The way in which the data were collected permits tests of two major hypotheses. The first is that there are no differences in mean weight of captures by the three types of traps. This is tested within species, within localities and with all the data pooled. Simply stated it asks if each type of trap catches the same size mice bath within each taxon and when all the taxa are pooled either by locality or totally. The second hypothesis states that there are no differences in the observed frequency of capture to the expected frequency of capture of each of the three types of traps. This also is tested within each species and with all taxa pooled by locality or totally. If all three types are equally effective, frequency of capture should be in direct proportion to the frequency of each kind of trap.

\section{RESULTS}

\subsection{Capture Weight and Trap Bias}

A total of 3,801 trap-nights produced 423 cricetid rodents belonging to 13 species. The bulk of the catch consisted of Phyllotis darwini plus two species of Akodon. When all species are pooled and examined by locality, it is clear that catches of the different types of traps are biased by weight (Table 1). At six of seven localities tested and when all localities are 
pooled, rat traps, on the average, catch the heaviest mice; Shermans catch the lightest mice; and Museum Specials catch those intermediate. $F$-values from analyses of variance demonstrate that these differences are significant or nearly so in six of the eight tests; lack of significance at Cailloma and Machupicchu probably reflects small sample size.

Table 1

Mean weights (grams) of all captures pooled by locality and for the entire study. $F$-tests suggest that the consistent trend of rat traps to capture the heaviest individuals and Shermans to capture the lightest weight individuals is the result of trap bias and not sampling (random) effects.

\begin{tabular}{lccccc}
\hline \multicolumn{1}{c}{ Locality } & Rat trap & Mus. spec. & Sherman & F-test & Deg. freedom \\
\hline Tacna & 45.9 & 36.1 & 30.1 & $4.68^{*}$ & $2 / 77$ \\
Moquegua & 45.8 & 43.6 & 35.8 & $4.56^{*}$ & $2 / 99$ \\
Chivay & 49.7 & 32.3 & 31.7 & $3.01^{\mathrm{e}}$ & $2 / 48$ \\
Santa Rosa & 38.0 & 31.0 & 27.5 & $2.73^{\mathrm{e}}$ & $2 / 79$ \\
Cailloma & 41.4 & 28.4 & 22.9 & 2.32 & $2 / 26$ \\
Pairumani & 32.1 & 27.1 & 23.8 & $2.71^{\mathrm{e}}$ & $2 / 58$ \\
Machupiccu & 21.0 & 22.6 & 28.7 & 1.21 & $2 / 13$ \\
All pooled & 41.0 & 34.1 & 29.9 & $6.91^{* * *}$ & $2 / 418$ \\
\hline
\end{tabular}

$* P \leqslant .05 \quad$ *** $P \leqslant .005 \quad$ e $P \cong .07$

Table 2

Mean weights and $F$-tests for the eight most abundant species pooled from all localities. The species are from the genus Phyllotis or Akodon.

\begin{tabular}{lccccc}
\hline \multicolumn{1}{c}{ Species } & Rat trap & Mus. spec. & Sherman & F-test & Deg. freedom \\
\hline P. darwini & 49.4 & 43.2 & 36.5 & $8.79 * * *$ & $2 / 164$ \\
P. magister & 62.4 & 64.5 & 53.7 & 0.89 & $2 / 15$ \\
P. osilae & 39.3 & 30.0 & 27.0 & 1.69 & $2 / 19$ \\
P. sublimis & 31.5 & 35.3 & 28.6 & 0.46 & $2 / 10$ \\
$P$. pictus & 39.3 & 41.3 & 38.6 & 0.14 & $2 / 18$ \\
A. berlepschii & 30.5 & 24.6 & 22.6 & 2.82 & $2 / 52$ \\
A. boliviensis & 21.0 & 21.1 & 18.3 & 1.15 & $2 / 69$ \\
A. jelskii & 28.3 & 29.3 & 27.6 & 0.10 & $2 / 14$ \\
\hline
\end{tabular}

*** $P \cong .001 \quad$ e $P \cong .07$

It is difficult to draw firm conclusions from the data in Table 1 because the observed differences between traps may stem from either intraspecific or interspecific variation in trap response, or both. For example, dominance of larger species at the first five localities is reflected in the larger average captures by all the traps. In order to better assess the bias, the data were regrouped by species and further tested.

When each species is examined separately, three species, $P$. darwini, $A$. berlepschii and $P$. osilae, repeat the trend seen in Table 1 . Since 
these three taxa represent nearly $60 \%$ of the total catch, this suggests that an intraspecific bias is at least partially responsible for the results in Table 1. It does not however eliminate the possibility that interspecific differences in trap response are also contributing to the variation. Pto.

\subsection{Frequency Specific Trap Bias}

If certain species differentially avoid or favor one type of trap or another, this could also contribute to the differences observed in Table 1 because the taxa vary in size. To examine this possibility, it was first necessary to ask whether the three traps were equally effective in catching the various species in general. Data in Table 3 suggest they

Table 3

Comparison of the observed versus the expected captures of all species pooled by locality. Expected capture is based on the proportion of traps to the total catch. Note that expected catch in Shermans is approximately half the total because they constitute half the trap lines. Chi-square values indicate that Shermans catch far fewer individuals then expected and snap traps, especially Museum Specials, catch many more than are expected by chance alone.

\begin{tabular}{lrrrrrrr}
\hline \multirow{2}{*}{ Localities } & \multicolumn{2}{c}{ Rat } & \multicolumn{2}{c}{ traps } & \multicolumn{2}{c}{ Mus. spec. } & \multicolumn{2}{c}{ Sherman } & \multirow{2}{*}{$\chi^{2}$} \\
& Obs & Exp & Obs & Exp & Obs & Exp & \\
\hline Tacna & 24 & 20 & 28 & 21 & 28 & 40 & $6.49^{*}$ \\
Moquegua & 23 & 25 & 41 & 26 & 38 & 51 & $11.35^{* *}$ \\
Chivay & 7 & 12 & 23 & 14 & 22 & 26 & $9.72^{* *}$ \\
Santa Rosa & 14 & 20 & 33 & 21 & 35 & 41 & $8.95^{*}$ \\
Cailloma & 5 & 7 & 5 & 8 & 19 & 14 & 2.80 \\
Pairumani & 20 & 15 & 28 & 16 & 15 & 32 & $18.40^{* * *}$ \\
Machupicchu & 3 & 4 & 6 & 4 & 6 & 7 & 1.53 \\
Pooled localities & 96 & 102 & 164 & 110 & 163 & 211 & $37.78^{* * *}$ \\
\hline
\end{tabular}

$* P \leqslant .05 \quad$ ** $P \leqslant .01 \quad$ *** $P \leqslant .005$

are not. Museum Specials caught between 33 and 78 percent more animals than expected at six of seven localities and 51 percent more than expected when all localities are pooled. Rat traps caught slightly more than expected at two localities and showed deficits of between eight and 42 percent at the other five localities. Rat traps did best at localities where the three heaviest species, $P$. darwini, $P$. magister, and $P$. osilae were the dominant rodents (i.e., Tacna, Moquegua and Pairumani). When all data are pooled, rat traps caught only slightly fewer animals than expected. The Shermans were the least effective traps showing deficits of between 14 and 53 percent at six of the seven localities with a pooled deficit of 22 percent.

To determine if this bias was caused by all the rodents or only certain 
taxa, the data were again regrouped according to species. Chi-square tests indicate that not all species are contributing equally to observed differences among traps (Table 4). P. darwini and P. osilae, both large species are adverse to entering live traps (41\% deficit) and are best taken by the Museum Special ( $58 \%$ excess), although rat traps are also

\section{Table 4}

Comparison of the observed versus the expected captures of the eight most abundant species pooled for all localities. Several of the more abundant species deviate significantly from expected captures and the same general trend is reflected in the other species. The total pooled group includes five rarer species not tabulated above as follows: Calomys sorellus $(\mathrm{n}=11)$, Akodon andinus $(\mathrm{n}=12)$, A. amoenus $(\mathrm{n}=11)$, Neotomys ebriosus $(\mathrm{n}=2)$, Oryzomys longicaudatus $(\mathrm{n}=1)$.

\begin{tabular}{lrrrrrrr}
\hline \multicolumn{1}{c}{ Species } & \multicolumn{2}{c}{ Rat traps } & \multicolumn{2}{c}{ Mus. spec. } & \multicolumn{2}{c}{ Shermans } & $\chi^{2}$ \\
& Obs & Exp & Obs & Exp & Obs & Exp & \\
\hline P. darwini & 47 & 40 & 67 & 44 & 54 & 84 & $24.20^{* * *}$ \\
P. osilae & 8 & 6 & 12 & 6 & 3 & 12 & $18.40^{* * *}$ \\
P. pictus & 3 & 5 & 6 & 6 & 12 & 10 & 1.06 \\
P. magister & 5 & 4 & 6 & 5 & 7 & 9 & 0.92 \\
P. sublimis & 2 & 3 & 3 & 3 & 8 & 6 & \multicolumn{1}{c}{0.70} \\
A. boliviensis & 13 & 18 & 32 & 19 & 28 & 36 & $11.83^{* *}$ \\
A. berlepschii & 10 & 13 & 19 & 14 & 26 & 28 & 2.40 \\
A. jelskii & 3 & 4 & 5 & 4 & 9 & 8 & 0.41 \\
All pooled & 96 & 102 & 165 & 110 & 163 & 211 & $37.78^{* * *}$ \\
\hline
\end{tabular}

$* * P \leqslant .01 \quad$ *** $P \leqslant .001$

effective ( $20 \%$ excess).

$P$. pictus and $P$. magister are similar in size to $P$. darwini but neither shares darwini's aversion for live traps. The small $A$. boliviensis is best taken with Museum Specials (68\% excess) and seems adverse to entering Shermans $(22 \%$ deficit). The remaining species are of medium to small size and show no statistically discernable bias in trap response however their small sample sizes must make any conclusions that bias is absent tentative.

\section{DISCUSSION}

\subsection{Trap Effects}

The tendency for the different traps to catch different sized rodents may reflect trigger sensitivity in the traps, differential trap response by the rodents or both. The data cannot reveal whether there is differential attraction to the traps and I must assume the observed catci differences stem from interactions after discovery of the traps. The 
larger size and stiffer trip mechanism of rat traps intuitively suggest greater force is required for release of the kill bar. The data are consistent with this idea. In all seven comparisons (localities) rat traps averaged the heaviest mice (Table 1). The ranges of weights (Table 5) also support this idea. Rat traps never caught the minimum weight individual at any locality and the average minimum weight exceeds that of both other traps.

The Museum Special appears to be a more versatile trap. Its smaller size suggests greater sensitivity than the rat trap and this is reflected by consistent catches of the smallest mice at each locality (Table 5). However it appears to match the capability of rat traps in taking large individuals of most species as well (Tables 2 and 5).

Data in Table 1 indicate rat traps are most effective with larger phenotypes but data in Table 2 indicates Museum Specials are more effective with larger size mice, at least intraspecifically. This seeming contradiction is easily explained in terms of interspecific differences in trap response. Rat traps are less effective for smaller species such as Akodon (Table 4) thus driving their average locality weight higher (Table 1). Museum Specials are effective with all size taxa resulting in an intermediate weight when the catch is pooled at each locality. It seems likely then that differences between rat trap and Museum Special reflect different mouse size optima as a function of trap size and trigger sensitivity rather than differential attraction to or behavior toward the traps.

Table 5

Size ranges of mice by weight (grams) captured by each trap type.

\begin{tabular}{lccrcrc}
\hline \multicolumn{1}{c}{ Localities } & \multicolumn{2}{c}{$\begin{array}{c}\text { Rat } \\
\text { Min }\end{array}$} & $\begin{array}{c}\text { Max } \\
\text { Max }\end{array}$ & $\begin{array}{c}\text { Mus. } \\
\text { Min }\end{array}$ & Max & \multicolumn{2}{c}{$\begin{array}{c}\text { Sherman } \\
\text { Min }\end{array}$} & Max \\
\hline Tacna & 14 & 88 & 8 & 94 & 9 & 62 \\
Moquegua & 20 & 73 & 14 & 74 & 14 & 71 \\
Chivay & 29 & 66 & 11 & 60 & 10 & 71 \\
Santa Rosa & 13 & 65 & 9 & 68 & 9 & 53 \\
Cailloma & 13 & 87 & 11 & 44 & 10 & 53 \\
Pairumani & 13 & 59 & 13 & 47 & 13 & 46 \\
Machupicchu & 14 & 27 & 12 & 29 & 15 & 45 \\
Average & 17 & 66 & 11 & 59 & 11 & 58 \\
\hline
\end{tabular}

The situation with Sherman traps is simpler. Larger mice are reluctant to, or cannot, enter the confined space of the trap. The trap is less effective with the larger individuals within species and with the larger taxa within communities (Tables 2 and 4). The largest individual caught in a Sherman was about $20 \%$ lighter than any from either of the other traps (Table 5). 
Trigger sensitivity does not seem to be a factor because Shermans, like Museum Specials, consistently captured minimum size specimens at each locality (Table 5). Morris (1968) and Qu a s t \& How ard (1953) in explaining differential species response to live-trap designs suggested that large species might be reluctant to enter the confines of smaller types of live-traps.

Results from this study parallel the findings of Wi e n e r \& S mith (1972) and S mith et al. (1971) that the Museum Special is a more versatile trap compared to several other designs. The results also parallel those of $\mathrm{N} \mathrm{e} \mathrm{a} 1$ \& C o c k (1969) and G ra n t (1970) in that different trap designs pose a "treatment effect " on average capture weight. These differences can probably be attributed to trigger sensitivity in the snap traps and unwillingness or inability of larger mice to enter the confined space of a live-trap.

Although consistent use of any capture method will sometimes be sufficient for comparative studies, use of inadequate or biased sampling will diminish accuracy of actual population parameters. Ideally, the sample should represent all components of the community in proportion to which they exist. The Chi-square analyses suggest that the three types of traps used in this study will produce different results regarding density or diversity if used separately. The potential for underestimating (O'Farrell \& Ka ufmann, 1975) or entirely missing (Edwards, 1952) certain component species in the community is also evident.

For example, rat traps accounted for only two of 21 Akodon caught at Moquegua, one of $13 \mathrm{~A}$. boliviensis caught at Chivay, and one of ten A. jelskii caught at Santa Rosa. When species were rare (especially small size taxa), rat traps often failed to demonstrate their presence. The catch at Chivay included $13 \mathrm{~A}$. boliviensis, two $\mathrm{A}$. amoenus, two $A$. andinus, one $A$. jelskii, five $P$. pictus, five $P$. sublimis and eight C. sorellus. Of these seven species and 36 specimens, rat traps produced only one $A$. boliviensis and one $P$. pictus, probably because most of these are small size taxa. Rat traps failed to reveal the presence of $P$. sublimis at three of four localities where it was present in low to moderate numbers. The other trap types on occasion also showed similar, albeit less dramatic biases. Shermans accounted for only three of $23 \mathrm{P}$. osilae trapped at Pairumani. Museum Specials failed to reveal the presence of A. jelskii at Cailloma and $P$. pictus at Chivay even though other traps revealed these species to be in modest abundance.

Since such data are important to environmental impact studies, their accuracy could influence decisions which alter land use policy and hence 
the ecology of an area. Utilization of several trap designs may be the best strategy in sampling a diverse community.

\subsection{Bait and Diet Effects}

Bait was unvaried in this study to eliminate confusion with other treatment effects but this in itself may have also been a source of bias. Since bait preference varies among species (P a tric, 1970), any correlation between species size and favored bait used might influence the catch. Most species of Phyllotis are large bodied and omnivorous but lean toward a vegetative diet. Most species of Akodon are small bodied but lean heavily toward an insectivorous diet (unpublished data). Using a vegetative bait (oats) may have biased the total sample in favor of the phyllotines and may explain the absence of certain species from any traps such as Andinomys, Eligmodontia and $P$. boliviensis known to occur in the area ( $c f . \mathrm{Pe}$ a r son, 1951). Although this would not affect relative trap effectiveness its implications for sampling faunal composition and density are clear. Utilization of a mixed bait might remedy such problems (op. cit.).

\subsection{Significance and Conclusions}

These analyses should serve as a caveat to students of mammalian eco-geographic variation. Significant treatment affects of traps on weight were found for $P$. darwini and $A$. berlepschii (Table 2). If weight reflects size differences, the results imply that utilization of museum specimens of unknown capture method to elucidate subtle patterns of size variation may pose a potential but unknown bias.

I envision two means to alleviate this problem. The first is to include method of capture on specimen labels as standard collecting practice. Since many museums have formulated labels, a place for this could be included in future label designs, but unfortunately this is no help for specimens already in collections. Since statistical bias is nothing more than an artificial but consistent directional shift of the mean, randomizing specimens in terms of collector or trapping method would reduce bias. Pooling of specimens and using large samples may be the best strategy to extract the least biased information from museum specimens.

Assessment of micro-distributional patterns, competitive interactions and associated ecological phenomena between species could also be confounded by trapping bias. Observed differences attributed to evolutionary or ecological phenomena might actually reflect trap sensitivity or animal behavior. Studies which utilize trapping should ideally include 
advance tests of trap designs and trapping procedures to optimize methods available to study a particular small-mammal fauna.

Acknowledgments: Special thanks are extended to William S. and Janet K. Street for their generosity in funding and directly assisting with field work in Peru. Dr. Oliver P. Pearson generously shared his knowledge of Peru and. Peruvian mammals as well as his field resources. The hospitality and assistance of Dr. Hernando de Macedo during our stay in Lima is graciously acknowledged as is the field assistance of D. M.Mortimer and R. V. Estrada. Dr. Antonio Brach-Egg facilitated issuance of a collecting permit. Reviews by Professors M. H. Smith, R. S. Hoffmann and T. L. Poulson led to substantial improvement of the manuscript and financia support came from the Field Museum, National Science Foundation (Grant Nc BMS 75-20272) and the University of Illinois Chicago Circle Computation Center.

\section{REFERENCES}

1. Cockrum E. L., 1947: Effectiveness of live versus snap traps. J. Mamm., 28: 196.

2. Dalby P. L. \& Straney D. O., 1976: The relative effectiveness of two sizes of Sherman live traps. Acta theriol., 21: 311-313.

3. Dice L. R., 1931: Methods of indicating the abundance of mammals. J. Mamm., 12: $376-381$.

4. D u r a n J. C., 1969: A comparison of live traps with snap traps. J. Ariz. Acad. Sci., 5: 18.

5. Edwards R. Y., 1952: How efficient are snap traps in taking small mammals? J. Mamm., 33: 497-498.

6. Fit $\mathrm{ch}$ H. S., 1954: Seasonal acceptance of bait by small mammals. J. Mamm., 35: $39-47$.

7. Gentry J. B. \& Odum E. P., 1957: The effect of weather on winter activity of old-field rodents. J. Mamm., 38: 72-77.

8. Grant P. R., 1970: A potential bias in the use of Longworth traps. J. Mamm., 51: $831-835$.

9. Gray J. A. Jr., 1943: Rodent populations in the sagebrush desert of the Yakima Valley, Washington. J. Mamm., 24: 191-193.

10. Manville R. H., 1949: Techniques for capturing and marking of small mammals. J. Mamm., 30: 27-33.

11. Morris R. F., 1955: Population studies on some small forest mammals in eastern Canada. J. Mamm., 36: 21-35.

12. Morris R. F., 1968: A comparison of capture success between Sherman and Longworth live traps. Can. Field Nat., 82: 84-88.

13. N e a l B. R. \& C o ck A. G, 1969: An analysis of the selection of small African mammals by two break-back traps. J. Zool., 158: 335-340.

14. N i e H. N., Hull C. H., Jenkins J. G., Steinbrenner K. \& Bent D. H., 1975: Statistical package for the social sciences. McGraw Hill, 2 ed. New York.

15. O'Farre11 M. J. \& Ka ufmann D. W., 1975: Aspects of activity for Peromyscus polionotus using a sand tracking technique. J. Mamm., 56: 525-528.

16. Patric E. F., 1970: Bait preference in small mammals. J. Mamm., 51: 179-182.

17. Pears on O. P., 1951: Mammals in the highlands of southern Peru. Bull. Mus. Comp. Zool., 106: 117-174. Harvard. 
18. Pearson O. P., 1958: A taxonomic revision of the rodent genus Phyllotus. Univ. Calif. Publ. Zool., 56: 391-496.

19. Pearson O. P., 1972: New information on ranges and relationships within the rodent genus Phyllotis in Peru and Ecuador. J. Mamm., 53: 677-686.

20. Pucek Z. \& Olszewski J., 1971: Results of extended catches of rodents. Ann. Zool. Fennici, 8: 37-44.

21. Quast J. C. \& Howard W. E., 1953: Comparison of catch of two sizes of small-mammal live traps. J. Mamm., 34: 514-515.

22. S e a la nder J. A. \& J a mes D., 1958: Relative efficiency of different smallmammal traps. J. Mamm., 39: 215-223.

23. Smith G. C., Kaufmann D. W., Jones R. M., Gentry J. B. \& S mith M. H., 1971: The relative effectiveness of two types of snap traps. Acta theriol., 16: 284-288.

24. Smith M. H., 1968: A comparison of different methods of capturing and estimating numbers of mice. J. Mamm., 49: 455-462.

25. Smith M. H. \& Blessing R. W., 1969: Trap response and food availability. J. Mamm., 50: 368-369.

26. Sokal R. R. \& Rohlf J. F., 1969: Biometry. W. H. Freeman: 1-776. San Francisco.

27. Van Vleck D. B., 1968: Movements of Microtus pennsylvanicus in relation to depopulated areas. J. Mamm., 49: 92-103.

28. W e in er J. G. \& S mith M. H., 1972: Relative efficiencies for four smallmammal traps. J. Mamm., 53: 868-873.

Accepted, March 10, 1979.

\section{J. J. PIZZIMENTI}

WZGLĘDNA EFEKTYWNOSC TRZECH TYPOW PUŁAPEK NA MAŁE SSAKI

\section{Streszczenie}

Badania prowadzono na 8 peruwiańskich gatunkach małych ssaków. Porównywano skład gatunkowy i klasy wielkości zwierząt łapanych przy użyciu trzech rospolicie stosowanych typów pułapek ustawionych na powierzchniach liniowych. Każda linia zawierała 25 punktów łownych w odstępach co $10 \mathrm{~m}$. Powierzchnie zlokalizowano w różnych miejscach (Tabela 1). Stwierdzono, że typ pułapki może wprowadzać zakłócenia w ocenie zróżnicowania wielkości i różnorodności gatunków ssaków. Pułapki na szczury McGilla są bardzo skuteczne do odłowu większych ssaków. Pułapki żywołowne Shermana dają lepsze wyniki przy odłowie mniejszych fenotypów i gatunków. Pułapki zatrzaskowe typu „Museum Special” wykazały największą uniwersalność łowiąc osobniki o różnej wielkości i z różnych gatunków (Tabela 2). Dodatkowo mają tę zaletę, że dzięki nim uzyskuje się największą różnorodność składu złowień; szczurze pułapki są pod tym względem pośrednie a najuboższy skład dają pułapki żywołowne Shermana (Tabela 3, 4).

Wyniki tej analizy mogą służyć jako ostrzeżenie dla badaczy populacji ssaków, ponieważ używanie poszczególnych typów pułapek i danych z odłowów może czasami prowadzić do ukrytych błędów wypływających z metodyki odłowów. 